\title{
Nutritive value of pods of indigenous browsable tree species in a semiarid area of Zimbabwe
}

\author{
LR Ndlovu, HM Sibanda, LM Sibanda, E Hove \\ Faculty of Agriculture, Harare, Zimbabwe
}

Livestock in smallholder farming systems of Zimbabwe are depended on indigenous browse tree pods as sources of nitrogen and energy during the dry season. The chemical composition and nutritive value of these pods is largely unknown.

The aim of this experiment was to determine the chemical composition, content of antinutritive factors and in vitro organic matter digestibility (IVOMD) of pods of Dichrostachys cinerea, Acacia ingrescens, Acacia tortilis and
Bauhinia thonningii. The content of antinutritive factors was determined by assaying for proanthocyanidins using the acid butanol method and by the radial diffusion method.

The IVOMD of the pods was low but this did not seem to be related to proanthocyanidin concentration or tannin binding effect on protein. The digestibility varied inversely with NDF content. The pods have a potential use as protein and energy supplements during the dry season, especially $A$. tortilis pods.

\begin{tabular}{lcccccc}
\hline Pod Species & $\begin{array}{c}\text { Dry matter } \\
(\mathrm{g} / \mathrm{kg})\end{array}$ & $\begin{array}{c}\text { NDF } \\
(\mathrm{g} / \mathrm{kg})\end{array}$ & $\begin{array}{c}\text { Crude Protein } \\
(\mathrm{g} / \mathrm{kg})\end{array}$ & $\begin{array}{c}\text { IVOMD } \\
\text { Vanillin Radial } \\
\text { Absorbance } \\
\text { A 550/g }\end{array}$ & $\begin{array}{c}\text { Tannins } \\
\text { diffusion } \\
\text { Activity }\end{array}$ \\
$\begin{array}{l}\text { Dichrostarchys Cinerea } \\
\text { Acacia ingrescens }\end{array}$ & 949 & 613 & 115 & 310 & 0.15 & 318 \\
Bauhinia thonningii & 950 & 465 & 149 & 360 & 0.30 & 150 \\
Acacia tortilis & 957 & 557 & 52 & 343 & 0.45 & 139 \\
& 938 & 360 & 147 & 520 & 0.24 & 271
\end{tabular}

